\title{
HUBUNGAN OBESITAS DENGAN TERJADINYA OSTEOARTRITIS LUTUT PADA LANSIA KECAMATAN LAWEYAN SURAKARTA
}

\author{
Annas Syahirul Nugraha, ${ }^{1}$ Sigit Widyatmoko, ${ }^{2}$ Safari Wahyu Jatmiko ${ }^{1}$ \\ 1. Fakultas Kedokteran Universitas Muhammadiyah surakarta \\ 2. Rumah Sakit Umum Daerah Simo Boyolali \\ Email: Safari.wahyu@ums.ac.id
}

\begin{abstract}
ABSTRAK
Prevalensi osteoartritis di Indonesia mencapai 15,5\% pada pria dan 12,7\% pada wanita. Osteoartritis merupakan penyakit sendi degeneratif yang berkaitan dengan kerusakan kartilago sendi. Obesitas adalah kelebihan berat badan melebihi berat normal. Obesitas menjadi faktor risiko osteoartritis lutut karena terjadi penambahan berat badan yang mengakibatkan sendi lutut bekerja lebih keras. Beberapa faktor lain yang dapat menyebabkan osteoartritis antara lain bertambahnya usia, jenis kelamin, genetik, dan pekerjaan. Jenis penelitian termasuk analitik observasional dengan pendekatan studi cross sectional. Jumlah sampel yang diteliti sebanyak 50 yang terdiri dari 25 lansia dengan obesitas dan 25 lansia tidak obesitas. Instrumen yang digunakan pada penelitian antara lain timbangan berat badan, alat pengukur tinggi badan dan kriteria osteoartritis sendi lutut berdasarkan American College of Rheumatologi. Data yang diperoleh kemudian dianalisis menggunakan uji chi-square dengan program SPSS versi 22 berbasis windows. Berdasarkan hasil analisa data menggunakan uji chi-square didapatkan hasil $p=0,001$ ( $p<0,005)$, yang berarti terdapat hubungan obesitas dengan terjadinya osteoartritis lutut pada lansia di Laweyan Surakarta.
\end{abstract}

Kata kunci: Obesitas, Osteoartritis, Lansia.

\begin{abstract}
The prevalence of osteoarthritis in Indonesia reached $15.5 \%$ in men and $12.7 \%$ in women. Osteoarthritis is a degenerative joint disease that is associated with damage to the articular cartilage. Obesity is excess body weight exceeds normal weight. Obesity is a risk factor for osteoarthritis of the knee due to the weight gain that resulted in the knee joint work harder. Some other factors that may cause osteoarthritis include age, gender, genetic, and work. This type of research, including analytical observational cross-sectional study approach. The number of samples examined 50 of 25 elderly obese and 25 non-obese elderly. The instruments used in the study include scale weight, height gauges and criteria for osteoarthritis of the knee joint by the American College of Rheumatology. The data obtained were analyzed using chi-square test with SPSS version 22 windows based.Based on the analysis of data using chi-square test showed $p=0.001(p<0.005)$, which means that there is a relationship of obesity with the occurrence of knee osteoarthritis in the elderly in Surakarta Laweyan.
\end{abstract}

Keywords: Obesity, Osteoarthritis, The elderly.

\section{Pendahuluan}

Obesitas adalah suatu kondisi dimana perbandingan berat badan dan tinggi badan melebihi standar yang ditentukan. Obesitas merupakan peningkatan total lemak tubuh, yaitu apabila ditemukan kelebihan berat badan $>20 \%$ pada pria dan $25 \%$ pada wanita karena lemak (Ganong, 2012). Meningkatnya obesitas tidak lepas dari gaya hidup, seperti menurunnya aktivitas fisik. Faktor genetik juga menentukan mekanisme pengaturan berat badan melalui pengaruh hormon dan neural (Limanan \& Prijanti, 2013).

Berdasarkan hasil Riset Kesehatan Dasar (Riskesdas) Indonesia tahun 2010, angka overweight dan obesitas pada penduduk usia di atas 18 tahun tercatat sebanyak 27,1\%. Prevalensi obesitas pun lebih tinggi di daerah perkotaan dibanding dengan pedesaan. Berdasarkan jenis 
kelamin prevalensi obesitas pada perempuan lebih tinggi (32,9\%) dibanding laki-laki $(19,7 \%)$ (RISKESDAS, 2010).

Osteoartritis merupakan penyakit sendi degeneratif yang berkaitan dengan kerusakan kartilago sendi.Vertebra, panggul, lutut, pergelangan kaki paling sering terkena osteoartritis. Berdasarkan WHO prevalensi osteoartritis di Indonesia mencapai 8,1\% dari total penduduk. Di Jawa Tengah kejadian osteoartritis sebesar 5,1\% dari semua penduduk (Maharani, 2007).

Para ahli yang meneliti penyakit ini sekarang sepakat bahwa osteoartritis merupakan penyakit gangguan homeostasis metabolisme kartilago dengan kerusakan struktur proteoglikan kartilago yang penyebabnya multifaktorial, antara lain karena faktor umur, stress mekanis atau penggunaan sendi yang berlebihan, obesitas, genetik, humoral, dan defek anatomik. Osteoartritis terjadi sebagai hasil kombinasi antara degradasi rawan sendi, remodeling tulang dan inflamasi cairan sendi. Remodeling tulang menyebabkan pembentukan tulang baru pada trabekula subkondral dan terbentuknya tulang baru pada tepi sendi. Reaksi remodeling tulang juga menyebabkan degenerasi permukaan artikuler pada sendi osteoartritis tidak bersifat progresif (Soeroso et al., 2007).

\section{Metode Penelitian}

Penelitian ini menggunakan desain penelitian analitik observational dengan pendekatan studi cross sectional untuk mempelajari adanya hubungan obesitas dengan terjadinya osteoartritis sendi lutut pada lansia (Notoatmojo, 2010). Penelitian ini dilakukan di beberapa posyandu lansia di Kelurahan Kerten Kecamatan Laweyan Surakarta dengan waktu penelitian bulan Desember 2014. Populasi target adalah semua lansia yang tinggal di wilayah Kerten Laweyan, sedangkan populasi aktualnya adalah semua lansia yang menjadi anggota posyandu lansia di Kelurahan Kerten Laweyan.

Subjek penelitian adalah lansia yang bersedia menjalani penelitian dan sesuai dengan kriteria restriksi. Jumlah subjek penelitian ada 50 sampel, dari 50 sampel dibagi menjadi 2 kelompok yang sama jumlahnya, yaitu 25 sampel dengan obesitas dan 25 sampel tidak obesitas.
Kriteria inklusi pria dan wanita lansia kelurahan Kerten yang bersedia mengikuti penelitian sampai akhir dan responden mampu melakukan instruksi penelitian sampai akhir. Kriteria ekslusi adanya riwayat trauma sendi lutut dan usia kurang dari 46 tahun.

Obesitas adalah berat badan lebih yang proporsinya tidak sesuai dengan tinggi badan. Obesitas dapat diukur dengan IMT (Indeks Masa Tubuh). IMT adalah indikator untuk mengetahui status kegemukan dengan rumus sebagai berikut (Sugonda, 2007). Osteoartritis adalah penderita osteoartritis lutut dengan kriteria yang disesuaikan dengan kriteria diagnosis osteoartritis genue (Sugonda, 2007).

Pengumpulan data dilakukan dengan cara mengukur IMT dari masing - masing subjek dan dikelompokan menjadi dua kelompok yaitu kelompok obesitas dan kelompok tidak obesitas. Langkah selanjutnya mengidentifikasi subjek dengan menggunakan kriteria diagnosis osteoartritis menurut American College of Rheumatology. Analisis data menggunakan analisis bivariat dengan uji statistik chi-square komparatif kategorik. Analisis data menggunakan software IBM SPSS Statistic 21.0 berbasis Windows.

\section{Hasil dan Pembahasan}

Jumlah subjek penelitian ada 50 sampel, dari 50 sampel dibagi menjadi 2 kelompok yang sama jumlahnya, yaitu 25 sampel dengan obesitas dan 25 sampel tidak obesitas.

Tabel 5. Distribusi nilai IMT berdasar jenis kelamin

\begin{tabular}{cccc}
\hline \multirow{2}{*}{ Jenis Kelamin } & \multicolumn{2}{c}{ Nilai IMT responden } & Total \\
\cline { 2 - 3 } & Obesitas & Tidak obesitas & \\
\hline Laki - laki & 5 & 8 & 13 \\
Perempuan & 20 & 17 & 37 \\
Total & 25 & 25 & 50 \\
\hline
\end{tabular}


Tabel 6. Distribusi nilai Osteoartritis berdasar jenis kelamin

\begin{tabular}{cccc}
\hline \multirow{2}{*}{ Jenis Kelamin } & \multicolumn{2}{c}{ Nilai OA responden } & Total \\
\cline { 2 - 3 } & OA + & OA - & \\
\hline Laki - laki & 5 & 8 & 13 \\
Perempuan & 12 & 25 & 37 \\
Total & 17 & 33 & 50 \\
\hline
\end{tabular}

Tabel 7. Distribusi nilai IMT dan nilai Osteoartritis Jenis kelamin

\begin{tabular}{cccccc}
\hline $\begin{array}{c}\text { Jenis } \\
\text { Kelamin }\end{array}$ & $\begin{array}{c}\text { Tidak } \\
\text { Obesitas } \\
\text { OA }+\end{array}$ & $\begin{array}{c}\text { Tidak } \\
\text { Obesitas } \\
\text { OA - }\end{array}$ & $\begin{array}{c}\text { Obesitas } \\
\text { OA }+\end{array}$ & $\begin{array}{c}\text { Obesitas } \\
\text { OA - }\end{array}$ & Total \\
\hline $\begin{array}{c}\text { Laki- } \\
\text { laki } \\
\begin{array}{c}\text { Perem- } \\
\text { puan }\end{array}\end{array}$ & 3 & 5 & 2 & 3 & 13 \\
Total & 3 & 22 & 14 & 11 & 50 \\
\hline
\end{tabular}

Tabel 8. Hubungan obesitas dengan osteoartritis

\begin{tabular}{cccc}
\hline \multirow{2}{*}{ IMT responden } & \multicolumn{2}{c}{ Nilai OA responden } & \multirow{2}{*}{ Total } \\
\cline { 2 - 3 } & $\mathrm{OA}+$ & OA - & \\
\hline Obesitas & $14(28 \%)$ & $11(22 \%)$ & $25(50 \%)$ \\
Tidak Obesitas & $3(6 \%)$ & $22(44 \%)$ & $25(50 \%)$ \\
Total & $17(34 \%)$ & $33(66 \%)$ & $50(100 \%)$ \\
\hline
\end{tabular}

Sumber : Data primer penelitian 2014

Nilai expected kurang dari 5 jadi tabel $2 \mathrm{x}$ 2 ini layak untuk diuji chi-square. Hasil dari uji chi-square menunjukan nilai $\mathrm{X}^{2}$ adalah 10,784 dan nilai $\mathrm{p}=0,001$, yang berarti ada hubungan antara obesitas dengan terjadinya osteoartritis lutut pada lansia di Laweyan Surakarta.

\section{Pembahasan}

Dari hasil penelitian menunjukan proporsi osteoartritis lutut lebih banyak didapat pada responden yang obesitas dibandingkan pada responden yang tidak obesitas. Hasil ini sesuai dengan teori - teori yang telah ada tentang hubungan obesitas dengan osteoartritis.
Obesitas merupakan salah satu faktor resiko terjadinya osteoartritis lutut. Sendi lutut merupakan tumpuan dari setengah berat badan seseorang selama berjalan. Berat badan yang meningkat akan memperberat tumpuan pada sendi lutut. Pembebanan lutut dapat menyebabkan kerusakan kartilago, kegagalan ligamen dan struktur lain. Penambahan berat badan membuat sendi lutut bekerja lebih keras dalam menopang berat tubuh. Sendi yang bekerja lebih keras akan mempengaruhi daya tahan dari tulang rawan sendi. Rawan sendi akan rusak dan menyebabkan sendi kehilangan sifat kompresibilitasnya dan menyebabkan terjadinya perubahan biofisika yang berupa fraktur jaringan kolagen dan degradasi proteoglikan (Felson, 2012).

Populasi dengan berat badan lebih dan obesitas mempunyai faktor risiko osteoartritis lutut lebih besar dibanding dengan populasi dengan berat badan normal. Obesitas merupakan faktor risiko kuat bagi OA lutut bilateral maupun unilateral. Pada pengukuran IMT dan osteoartritis didapatkan dari 25 lansia obesitas terdapat 14 lansia yang menderita osteoartritis dan dari 25 lansia tidak obesitas didapatkan hanya 3 lansia yang menderita osteoartritis. Lansia yang tidak obesitas dan menderita osteoartritis sebanyak 3 lansia yang berumur diatas 70 tahun.

Usia juga merupakan faktor terjadinya penyakit osteoartritis. Penderita osteoartritis biasanya di atas 40 tahun dan bertambah berdasarkan peningkatan usia. Usia yang semakin bertambah menyebabkan penurunan fungsi dari tulang rawan sendi. Kekuatan kolagen pada lansia juga mengalami penurunan, hal ini bisa menyebabkan tulang rawan sendi menjadi lemah dan mudah rusak. Proses menua ada beberapa perubahan pada tulang dan sendi. Pada tulang terjadi pengurangan massa tulang dan berkurangnya formasi osteoblas tulang. Pada sendi terjadi gangguan matriks kartilago dan modifikasi proteoglikan dan glikosamaminoglikan (Johnson \& Hunter, 2014).

Di dalam penelitian ini ada beberapa kelemahan yang menyebabkan terjadinya bias. Pemeriksaan gold standart osteoartritis menggunakan pemeriksaan radiologis untuk mengetahui gambaran pada sendi yang terkena osteoarthritis (soeroso et al, 2007). Pada penelitian ini terdapat kekurangan yaitu dilakukan pemeriksaan fisik untuk mengetahui osteoartritis 
yang kemungkinan terdapat bias pada pemeriksaan yang dilakukan oleh peneliti. Variabel perancu yang tidak bisa dikendalikan adalah faktor genetik.

\section{Kesimpulan}

Terdapat hubungan obesitas dengan terjadinya osteoartritis lutut pada lansia di Laweyan Surakarta. Proporsi osteoartritis lutut lebih banyak didapatkan pada responden yang obesitas dibandingkan dengan responden yang tidak obesitas.

\section{Daftar Pustaka}

Felson D.T., 2012. Osteoartritis, in Harrison's Principles of Internal Medicine, Longo Dan L., Kasper Dennis L., Jameson J Larry., Fauci Anthony S., Hauser Stephen L., Loscalzo Joshep.18th ed. New York : The McGrawl - Hill Companies, Inc. 17 : 2828 $-36$

Ganong W.F., 2012. Buku Ajar Fisiologi Kedokteran Ganong. Novrianti A., Dany F., Resmisari T., Rachman L.Y., Muttaqin H., Nugroho A.W., Rendy L., Dwijayanthi L., Bourman
V (terjemahan). Edisi 22. Jakarta : EGC. 293 $-331$

Johnson V.L., Hunter D.J., 2014. The Epidemilogy of Osteoarthritis. Res Clinic Rheum. 28: 5-15

Limanan D., Prijanti A.R., 2013. Hantaran Sinyal Leptin dan Obesitas : Hubungan dengan Penyakit Kardiovaskuler. FK UI. Tesis.

Maharani E.P., 2007. Faktor - faktor Risiko Osteoartritis Lutut. FK UNDIP. Tesis.

Notoatmojo S., 2010. Metodologi Penelitian Kesehatan. Jakarta : Rineka Cipta. 130

RISKESDAS., 2010. Badan Penelitian Dan Pengembangan Kesahatan Kementrian Kesehatan RI. Diakses di http://www. litbang.depkes.go.id/. (Oktober 2014)

Soeroso J., Isbagio H., Kalim H., Broto R., Pramudiyo R., 2007. Osteoartritis, di : Buku Ajar Ilmu Penyakit Dalam. Sudoyo A.W., Setiohadi B., Alwi I., Simadiprata M.K., Setiati S., (Eds). Edisi 4. Jakarta : Pusat Penerbit Bagian Ilmu Penyakit Dalam FK UI. 1195 - 201

Sugonda S., 2007. Obesitas, di : Buku Ajar Ilmu Penyakit Dalam. Sudoyo A.W., Setiohadi B., Alwi I., Simadiprata M.K., Setiati S., (Eds). Edisi 4. Jakarta : Pusat Penerbit Bagian Ilmu Penyakit Dalam FK UI. $1919-25$ 